\title{
Effects of microbial communities on arsenic mobilization and enrichment in groundwater from the Datong Basin, China
}

\author{
L. Yan, X.J. Xie, K.F. Pi, K. Qian, J.X. Li, Z.Y. Chi \& Y.X. Wang \\ School of Environmental Studies \& State Key Laboratory of Biogeology and Environmental Geology, \\ China University of Geosciences, Wuhan, China
}

\begin{abstract}
The phospholipid fatty acids (PLFA) as biomarkers of microbial community structures were appointed to elaborate the mobilization of arsenic (As) in groundwater from Datong Basin. The results showed that saturated fatty acids 16:0, 18:0, monounsaturated fatty acids $16: 1 \omega 9,18: 1 \omega 9$, and cyclopropane fatty acids 17:0, 19:0 had relatively high contents. This may imply the significant impact of dominant Desulfobacter and Clostridium on the mobilization of As in the shallow groundwater. Sulfate-reducing bacteria and Fe-reducing bacteria can mediate the reductive dissolution of As-bearing Fe oxides/hydroxides to cause the release of As into groundwater.
\end{abstract}

\section{INTRODUCTION}

The exposure to high concentrations of arsenic (As) may be fatal to the human health. The genesis of high As groundwater is related to the reductive dissolution of As-bearing iron oxides/hydroxides in the aquifers (Pi et al., 2015). Microbes can mediate different redox reactions, which contributes to the release and enrichment of As in groundwater (Akai et al., 2008). The phospholipid fatty acids (PLFA), forming a major part of the bacterial cell membranes, are regarded to be indicators of living bacterial communities due to their rapid degradation after cell death, which can provide a quantitative measure of the viable biomass and biological diversity of microbial communities (Fang et al., 2006). In the present study, we analyzed lipid biomarkers and the geochemical characteristics of groundwater to illuminate the effects of microbial communities on As mobilization and enrichment in groundwater from the Datong Basin, China.

\section{METHODS/EXPERIMENTAL}

\subsection{Sampling and geochemical analysis}

The sediment samples were collected from a multilevel groundwater monitoring site in October, 2016 from Shanyin County of the Datong Basin, where As contaminated groundwater occurs. The fresh sediment samples were air-dried, ground, and sieved through a 200 gauge screen. After $0.05 \mathrm{~g}$ of the prepared sample was digested using ultra-pure concentrated $\mathrm{HNO}_{3}$ and $\mathrm{HF}$ at $180^{\circ} \mathrm{C}$ for $24 \mathrm{~h}$, the trace and major elements were tested using inductively coupled plasma mass spectroscopy (ICP-MS) and hydride generation atomic fluorescence spectrometry (HG-AFS), respectively. Total organic carbon (TOC) contents of the sediments were tested using an elemental analyzer (Vario EL cube, Elementar) after the samples were air-dried, ground to 200 mesh and cleaned of inorganic carbon with $0.1 \mathrm{M} \mathrm{HCl}$.

\subsection{PLFA analysis and statistical assay}

A mild alkaline methanolysis method was used to extract total PLFAs, which were then dissolved in $0.5 \mathrm{~mL}$ of $1: 1$ hexane:methyl-tert butyl ether and transferred to GC vials for analysis. The correlations of PLFAs contents in the samples were verified via applying principal components analysis using the Past 3.0 software package.

\section{RESULTS AND DISCUSSION}

\subsection{Sediment geochemistry}

The particle size of the core samples ranged from clay, silt to fine sand. The color of sediments varied from yellow-brown, brown to gray-black, the latter in line with the high TOC levels $(0.08 \mathrm{wt} . \%$ to $0.41 \mathrm{wt} . \%$, average $0.16 \mathrm{wt} . \%)$. The bulk As contents in sediments ranged from 7.20 to $91.6 \mathrm{mg} \mathrm{kg}^{-1}$ with an average value of $22.2 \mathrm{mg} \mathrm{kg}^{-1}$, far exceeding the average level of $5-10 \mathrm{mg} \mathrm{kg}^{-1}$ in typical modern sediments. The bulk Fe contents varied from $28.4 \mathrm{~g} / \mathrm{kg}$ to $51.0 \mathrm{~g} \mathrm{~kg}^{-1}$, with an average of $37.0 \mathrm{~g} \mathrm{~kg}^{-1}$. Total concentrations of the elements are relatively uniform among all samples, and showed tendency of enrichment in the finer clays. It indicated that trace elements such as $\mathrm{As}, \mathrm{Cu}, \mathrm{Ni}$ were subjected to the isologous geochemical processes in the sediments or had common sources and could be adsorbed by the oxides/hydroxides of $\mathrm{Fe} / \mathrm{Mn} / \mathrm{Al}$. 


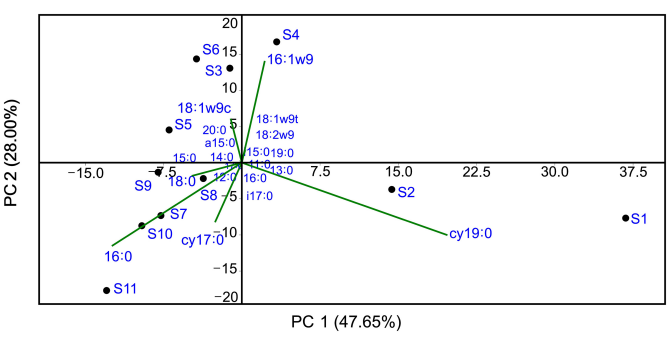

Figure 1. The principal component scattering of PLFAs in sediments from the Datong Basin.

There is a positive correlation between TOC and total As in the bulk sediments $\left(r^{2}=0.84\right)$, demonstrating As is prone to be enriched in clay sediments with high organic matter content. Dispersed sedimentary organic matter in the aquifer may be easily mobilized to groundwater to promote microbial reactions. Furthermore, the organic matter coated on the surface of Fe minerals can be used as electron donors to fuel in-situ reductive dissolution of Fe(III) oxides/hydroxides, releasing DOM, Fe(II) and As into groundwater.

\subsection{PLFA profiles}

PLFAs with chain length from $\mathrm{C}_{11}$ to $\mathrm{C}_{20}$ were detected in sediments from Datong Basin. The PLFA profiles were dominated by saturated straight even chain PLFAs (12:0, 14:0, 16:0, 18:0, 20:0), monounsaturated fatty acids $(16: 1 \omega 9,18: 1 \omega 9)$, cyclopropane fatty acids (cy17:0, cy19:0), and branched fatty acids (i15:0, a15:0, i16:0, i17:0), whose relative content was $24.31 \%-90.78 \%, \quad 11.71 \%-52.93 \%, \quad 7.64 \%-53.87 \%$ and $1.69 \%-4.70 \%$, respectively.

The PLFA profiles of the collected samples were analyzed by principle component analysis (PCA, Fig. 1). PC1 and PC2 accounted for $47.65 \%$ and $28.00 \%$ of the variances. Factor loading values were the projection of PLFAs on the corresponding ordination axis. The values manifested that 16:0, 18:0, cy19:0, cy17:0 had a strong positive relationship with $\mathrm{PC} 1$, which was positive to sulfate-reducing bacteria (SRB: Desulfobactor). The 16:1 $\omega 9$ and $18: 1 \omega 9 \mathrm{c}$ had good correlation with $\mathrm{PC} 2$, which indicated that Fereducing bacteria (FeRB: Clostridium) were positive to $\mathrm{PC} 2$.

\subsection{Specific PLFA analysis}

The contents of arsenic and cyclopropane fatty acids (cy17:0 + cy19:0) showed the negative relationship along the borehole, illustrating high abundant of SRB and FeRB would favor the mobilization of arsenic (Fig. 2). Under strongly reducing conditions, sulfate-reducing bacteria can reduce $\mathrm{SO}_{4}^{2-}$ and produce soluble sulfide. The dissolved sulfide can directly reduce As-bearing Fe(III) oxides/hydroxides. Simultaneously, FeRB may also cause the reductive dissolution of Fe(III) oxides/hydroxides and As release.

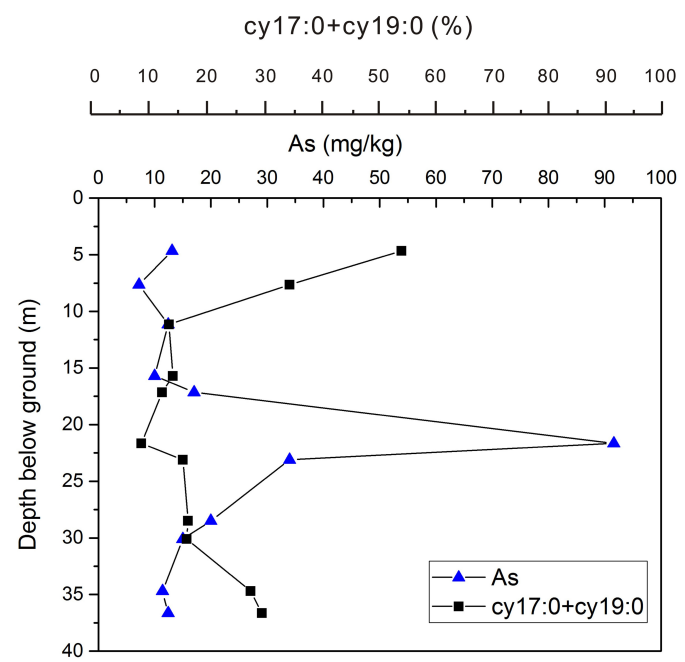

Figure 2. The depth profiles of the contents of arsenic and cyclopropane fatty acids (cy17:0 + cy19:0).

\section{CONCLUSIONS}

Biomarkers of anaerobia, such as sulfate-reducing bacteria and iron-reducing bacteria, were identified in sediments. The mobilization and enrichment of arsenic may have been controlled and influenced by different microbial communities and processes in shallow groundwater of the Datong Basin. In the high arsenic region, periodic irrigation activities input exogenous organic matter into subsurface, where SRB and FeRB can utilize OM for sulfate and $\mathrm{Fe}(\mathrm{III})$ reduction. The production $\mathrm{HS}^{-}$, could act a reducing agent for iron oxides/hydroxides, expediting the release of the bound arsenic to the groundwater.

\section{ACKNOWLEDGEMENTS}

The research work is financially supported by National Natural Science Foundation of China (Nos. 41372254, 41772255).

\section{REFERENCES}

Akai, J.J., Kanekiyo, A., Hishida, N., Ogawa, M., Naganuma, T., Fukuhara, H. \& Anawer, H.N. 2008. Biogeochemical characterization of bacterial assemblages in relation to release of arsenic from South East Asia (Bangladesh) sediments. Appl. Geochem. 23(11):3177-3186.

Fang, J.S., Chan, O., Joeckel, R.M., Huang, Y.S., Wang, Y., Bazylinski, D.A., Moorman, T.B. \& Ang Clenment, B.J. 2006. Biomarker analysis of microbial diversity in sediments of a saline groundwater seep of Salt Basin, Nebraska. Org. Geochem. 37(8):912-931.

Pi, K., Wang, Y.X., Xie, X.J., Huang, S.B., Yu.Q. \& Yu, M. 2015. Geochemical effects of dissolved organic matter biodegradation on arsenic transport in groundwater systems. J. Geochem. Explor. 149(149):8-21. 